\title{
Japan's Supreme Court Discourse and Lifetime Employment Cultural Cognition and U.S. Labor Relations
}

\author{
Tackney, Charles T.; Sato, Toyoko
}

\author{
Document Version \\ Final published version
}

Publication date:

2012

\section{License \\ CC BY-NC-ND}

Citation for published version (APA):

Tackney, C. T., \& Sato, T. (2012). Japan's Supreme Court Discourse and Lifetime Employment: Cultural Cognition and U.S. Labor Relations. Institut for Interkulturel Kommunikation og Ledelse, IKL. Copenhagen Business School.

Link to publication in CBS Research Portal

\section{General rights}

Copyright and moral rights for the publications made accessible in the public portal are retained by the authors and/or other copyright owners and it is a condition of accessing publications that users recognise and abide by the legal requirements associated with these rights.

\section{Take down policy}

If you believe that this document breaches copyright please contact us (research.lib@cbs.dk) providing details, and we will remove access to the work immediately and investigate your claim. 


\title{
Japan's Supreme Court Discourse and Lifetime Employment: Cultural Cognition and U.S.
} Labor Relations

\begin{abstract}
A Paper Submitted to the Social Issues in Management Division of the 2012 Academy of Management Conference
\end{abstract}

Charles T. Tackney, Ph.D.* and Toyoko Sato, Ph.D.

Email: ct.ikl@cbs.dk / torinomune@gmail.com

Phone: +45-3815-3815

Department fax: $+45-3815-3840$

Department of Intercultural Communication and Management

Copenhagen Business School

Porcelænshaven 18A

Frederiksberg, Denmark 2000

* - Primary/corresponding author. 


\begin{abstract}
Our study explores cultural cognition in comparative U.S. - Japan employment relations through interdisciplinary analysis of Japanese Supreme Court regulation of the post-World War II lifetime employment system and the latest data available on Japan's collective bargaining-based approach to employee participation in managerial prerogative. The comparative social policy aim is to examine and account for observed employment relations variance in the U.S. and Japan, given their similar labor legislation. Japan's Supreme Court recognizes lifetime employment as an institutionalized practice and we report all 236 references to the term "lifetime employment" in Japanese case law: 178 regional cases, 43 regional superior cases, and 15 Supreme Court cases. Quantitative analysis of Supreme Court cases contextualizes these references in postWorld War II history; qualitative analysis focuses on the Court's discourse. Causally related to this recognition, management councils (a form of employee participation in managerial prerogative) are also a defining feature of Japanese employment relations at the enterprise level. Despite unionization rate declines in both nations, the persistence of Japan's participatory employee relations system contrasts sharply with recent U.S. state-based legislative assaults on long-standing collective bargaining, particularly for public sector unions. The concept of cultural cognition, recently deployed in legal studies to account for domestic U.S. risk, public policy and voting preferences, offers theoretical grounds for better understanding of the observed comparative variance in employment practices. We conclude with proposals for organized labor in the U.S. to strengthen prospects for informal network proliferation and employee participation, with the goal of enhancing national competitiveness.
\end{abstract}

Keywords: social issues, cultural cognition, informal networks, industrial relations, comparative labor law, Japanese management, lifetime employment, judicial discourse. 
The 2012 Academy of Management Conference theme invites study of the "informal economy," defined as "commercial activities that occur at least partially outside a governing body's observation, taxation, and regulation." In this paper, we deploy cultural cognition in the explication of legal regulation of lifetime employment in Japan as an institutionalized practice, even though it is frequently characterized as a "traditional" or "informal" practice of Japan's postwar employment relations. We wish to highlight evident variance in post-World War II and current employment practice between the U.S. and Japan in respect to social issues in management and public policy, first at the macro-level of Supreme Court regulation and to account for the post-war structuring of Japan's institutionalized practice through just cause dismissal protection and the collective bargaining-based development of Japan's postwar management councils (in Germany and the EU, where legislatively based, works councils). We provide the most recently available data on these consultative bodies in Japan at the enterprise or micro-level of informal economic behavior.

In the latter half of the prior century, the comparative working rules of employment relations in the United States of American and Japan developed along their respective paths in reference to very similar labor legislation as a result of New Deal labor legislation, introduced to Japan in the wake of the Pacific War. As may be well known, Japan's labor laws come from Allied Occupation policy and the main acts are, functionally, translations of American New Deal labor law (Tackney, 1995). U.S. national labor legislation includes the Norris-LaGuardia Act (1932), the National Labor Relations Act (1935, "the Wagner Act”), and the Taft-Hartley Act (1947, “the Labor-Management Relations Act”). Major Japanese labor legislation includes the Trade Union Law (1946), the Labor Standards Law (1947), and the Labor Relations Adjustment Law (1947). In the U.S., the National Labor Relations Board (NLRB) functions an outcome of 
New Deal labor reforms; it is paralleled in Japan by the Central Labor Relations Commission, established by the Trade Union Law. Japan's Trade Union Law was enacted by the Japanese Diet even before the postwar Constitution was established. The Supreme Command Allied Powers (SCAP) point was simple and clear: successful democracy needs organized labor

Despite U.S. political commitment to the role of organized labor in American culture since the New Deal, with this being singularly evident as a matter of importance in the democratization of post-war Japan, the American experience of economic democracy has long viewed the workplace as a contested domain. The U.S. is famous for its "at will" employment pattern. Management councils of the sort that, as we shall see, have become normative in Japan remain flatly illegal, despite a call for experimentation by the Dunlop Commission (Dunlop Commission, 1994) and a sympathetic view of participatory Japanese management practice by a former NLRB Commissioner (Gould, 1984, 1993).

The competing domestic American perspective on employee voice becomes oddly manifest in the research literature. A recent review of extant studies offered the following, “integrated conceptualization of (employee) voice" as, "discretionary communication of ideas, suggestions, concerns, or opinions about work-related issues with the intent to improve organizational or unit functioning" (Morrison, 2011, p. 375). Despite the specification, the author then excludes studies of works councils and other organizational structures for formal voice expression on the grounds these do not address voice discretionary employee behavior (Morrison's emphasis), adding, "and as these various literature streams define voice in a way that does not closely match current conceptualizations, I exclude them from this review" (p. 381).

That step of exclusion is indicative of a cultural bias peculiar to the United States. It is arguably part of a persistent American cultural exceptionalism. In fact, the current 
conceptualization of employee voice and behavior is normatively manifest, both formally and informally, in management and works councils in every developed nation in the world except for the United States. ${ }^{1}$ Thus, Morrison's characterization is both accurate, yet signally constrained. It is accurate in that voice in the U.S. context is behaviorally optional if ever more individual, but it is constrained because on any comparative national level, the absence of structured participatory voice in the U.S. reflects social policy myopia of profound dimensions. Thus, the authors offer this comparative study as a particularly pertinent contribution to the 2012 Academy of Management Conference with its theme of "informal networks."

Contemporary evidence for employee participation as part of the idiosyncratic skills necessary for long-term employment and competitive success of the enterprise is compelling and long-established in network studies and the knowledge management literature (Foss, 1999; Nonaka 1995, 2005). Historically, there is also deep appreciation for the need of employee participation in managerial prerogative within the U.S. employment relations system. John R. Commons, known as the father of U.S. labor relations and founder of the "Wisconsin School," wrote, "In some concerns...even the wage earners, organized or unorganized, have a compelling voice in determining the direction and extent of management" (1924, p. 368). In light of this persisting and systemic cultural oversight, the authors offer this comparative study as a particularly pertinent contribution to the 2012 Academy of management conference, with its conference focus on the role and function of informal networks.

In fascinating and distinctive contrast to the U.S., Japan's working rules developed from a similar legislative base in very different ways. Lifetime employment as a post-World War II institutionalized practice developed from the postwar proliferation of collective-bargaining based management councils (keiei kyogikai) and case law recognition of just cause dismissal protection

\footnotetext{
${ }^{1}$ Despite lagged application, the U.K. admits to E.U. works councils. See http://www.fedee.com/ewc1.html .
} 
needs in the face of a fundamentally unequal employment contract (Kettler \& Tackney, 1997). These principles constitute the national set of "working rules" governing Japanese employment relations. They are based on Japan's civil code, post-World War II labor legislation and Constitution, subsequent judicial interpretation, and various administrative advisory codes. In this, Japan's set of "working rules" parallel those of any national industrial relations system (Commons, 1924; Dunlop, 1958, 1993; Kettler \& Tackney, 1997). Japan's employment relations system has persisted over time (Lincoln, J. R, 2004), including a major labor legislative reform in 1987 (Tackney, 2001).

Lifetime employment is a phrase associated with Japan's employment relations since 1958 texts by Abegglen and Levine. Further, issues associated with Japan's lifetime employment system are manifest in any number of fields - from industrial relations (Levine, 1958; Shimada, 1992), to sociology (Cole, 1979), management theory (Aoiki, 1988; Koike, 1988), the dense formal and informal networks extant in the keiretsu system (Gerlach, M.L., 1997; Lincoln, J. R, 2004) and even the realm of contextual theology (Schreiter, 1985). The tracing of norms to support its emergence in case law and, ultimately, Supreme Court decisions includes adapative appropriations from European, specifically Weimar-era labor law, which support just cause employment norms and employee participation in enterprise function (Kettler, Tackney, 1997).

Furthermore, the puzzle presented by the notion of lifetime employment remains vexing for reasons that are, in a sense, two dimensional. First, as the texts referenced above indicate, the basic debate over whether or not lifetime employment exists has a chronological dimension spanning the postwar decades. Second, misapprehensions or oversight regarding the nature of lifetime employment in Japan continue to result in research and claims regarding employment practices and management theory in Japan that would otherwise benefit from greater 
understanding of the judicial origins and regulation of both areas (Aoki, 1988; Beck \& Beck, 1994; Koike, 1988; Nonaka, 1995; Numagami, Karube, \& Kato, 2010). Aoki ascribed long-term employment patterns to employer reasonableness, the implication being U.S. counterparts do not share such levels of reasoning. Koike denied the existence of lifetime employment, blaming any claims of its existence on poor research methods. Nonaka, in turn, developed a knowledge management theory without any evident reference to the conditioning effects of Japan's unique "working rules" of just cause and management councils.

We will briefly summarize the evidence trail showing that Japan's lifetime employment system derived from post-World War II U.S.-styled labor legislation, combined with subsequent adaptive appropriations of continental European jurisprudence. Our goal, however, lies beyond. We will report Japan's Supreme Court rulings on cases acknowledging and regulating lifetime employment. We also report the latest available data on the proliferation of management participation forums in Japan. Taken together, these manifest a legal pattern that effectively institutionalized extensive, complex patterns of informal collaboration within and around Japan's workplace.

In sharp contrast, the American experiment in economic democracy since the 1980s has seen a contrary shift against organized labor. Any deployment of participation schemes has been at the behest of exclusively retained managerial prerogative, with profit shares - as one useful proxy for actual and authentic "participation" - only increasingly retained for executive compensation. Kochan, Katz, and McKersie characterized this as a pattern of "strategic choice" on the part of American management (Kochan, Katz, \& McKersie, 1986). Unionization of work sites were resisted, even with illegal practices. Labor union agreements were willingly abrogated, fines notwithstanding. Manufacturing sites were shifted to right to work states or abroad, or such 
moves threatened, upending what Dunlop had seen as the U.S. pattern of stable labor relations (Dunlop, 1958, 1993). Ironically, Kochen et al. cited increased competition from Japanese manufacturers to be one of the primary causes compelling U.S. management to take these strategic choices. That the nature of Japanese management success might have been due to a completely different, more inclusive form of labor relations was a lesson apparently lost to the U.S. managerial class - and this for reasons never adequately explained. Some lessons were learned, centering on manufacturing processes: Just-in-time production, kaizen, zero defects. Yet, a fundamental gap remained between the manner of management in the Japan context and that of the United States (Halberstam, 1986).

More recently, the shift Kochen et al. first observed in the 1980s has taken a more radical turn. We are now witness to direct assaults on the very legal fabric of labor organizations and collective bargaining, private as well as public sector, this last at state legislatures in Wisconsin, Illinois, Indiana, and elsewhere (Hogler \& Henle, 2011). Wisconsin Governor Scott Walker produced legislation aimed, prima facie, on restoring state solvency. Yet, his refusal to compromise on aspects of a bill that constrained long-standing collective bargaining procedures led commentators to conclude, "Walker's intent was to undermine the labor movement as part of a coordinated antiunion agenda rather than to stabilize state finances" (Ibid., p. 136). Against the background of steady loss of union membership, Hogler and Henle observed, "the result of union decline for most American workers is an ongoing decay of the institutional foundations of economic stability" (p. 137). ${ }^{2}$ Gould reported that American workers soon face the loss of even

\footnotetext{
${ }^{2}$ U.S. unionization rates have steadily declined from a post-World War II high of about $28 \%$ of employed workers in 1954 to $11.9 \%$ in 2010 ( http://digitalcommons.ilr.cornell.edu/cgi, http://www.bls.gov/news.release/union2.nr0.htm ). In Japan, peak unionization after World War II of around 55\% has declined to $18.1 \%$ in 2007 (http://www.mhlw.go.jp/toukei/itiran/roudou/roushi/kiso/07/kekka.html ).
} 
basic rights to union recognition, due to ideological conflict over NLRB appointments (December 16, 2011).

At the other end of the employment relations spectrum in the U.S. stands the astronomical increase in wage differentials between the average worker and executive (Moyers, 2006). This trend began in the 1980s; 2006 figures indicate an American executive compensation differential 487 times that of the average American worker. Comparable differentials for other developed nations reveal the extreme disparity of the U.S. case: Japan (11 times), Germany (12), France (15), and the United Kingdom (executive salary at 22 times that of the average worker) (Ibid.). ${ }^{3}$

To account for domestic U.S. polarization in public policy differential risk propensities among the electorate, U.S. legal scholars have lately taken up study of cultural cognition as a concept capable of explaining observed variance in election outcomes (Kahan, Dan M., 2006, 2011; Kahan, Dan M., Slovic, Braman, \& Gastil, 2006). The basic premise for legal studies of this concept is that cultural commitments come prior to factual knowledge in respect to political issues. Kahan wrote, "cultural commitments operate as a kind of heuristic in the rational processing of information on public policy matters" (2006, p. 149). Hogler and Henle (2011) applied this concept to the contemporary attack on U.S. public sector unions. They disaggregated anti - union sentiment to cultural cognition patterns on a four-item scalar that plots hierarchy egalitarian against individualism - communitarian variance. In post-Civil War American culture, the authors noted that right to work activists, "depended on political ideas involving free markets, race, individual autonomy, distrust of outsiders, and insularity" (p. 138). They traced this cultural cognitional 'set' or anticipatory heuristic through the 1980 election of Ronald Reagan to contemporary Tea Party and current anti - union state legislature activists. They found, in

\footnotetext{
${ }^{3}$ A detailed analysis of Japanese executive compensation from 2006 found the rate to be one-third to one-fourth that of U.S. executives (Nakazato, Ramseyer, \& Rasmusen, 2006).
} 
effect, "Right to work metastasized from its origins in the South and spread to its present dimensions by promoting American values to citizens in a competitive economic environment created by differential labor markets" (p.139).

If the cultural cognition approach is valid, then it would be of interest to comparatively evaluate postwar labor law trends in the Japan case for several reasons. First, Japanese culture is taken to be comparatively more hierarchical and communitarian than American culture, although Japanese management theory tends to stress flat, egalitarian participatory structures. Given the shared labor legislative foundation, the merits of such an international contrast are compelling. This paper would appear to be a first effort to that end and, accordingly, a corrective to the critique of domestic U.S. cultural cognition literature being too parochial (Kahan, 2011).

We might usefully end this review of literature and social policy by positing a hypothesis or two. First, labor law and jurisprudence in Japan should evidence greater distance along the egalitarian / communitarian parameters than trends in the U.S. Second, one significant measure of hierarchy, as this matter is complex in the Japanese culture case, could be the evidence concerning executive compensation levels. While Japan is famously hierarchical as a society with even verb endings being carefully differentiated along levels of hierarchical politeness following the money in a firm's profit distribution would be one very salient measure of how the parameter of hierarchy - egalitarian is comparatively manifest in the U.S. and Japan.

\section{METHOD}

This is an interdisciplinary research design that takes up the quasi-experimental design offered by U.S. and Japanese labor legislation similarities in order to effectively explore cultural cognition. We intend to use this design to usefully account for observed variance and infer practical policy proposals from reflection on findings. Having reviewed the literature on the 
subject and derived a few hypotheses, we begin this section by explaining the means of Supreme Court case reference discovery, the database resource, their methodological constraints, and the survey sources for Japan's management councils and other participatory forum data.

The Supreme Court data section has two parts. We first offer descriptive statistics on all case law references to this phrase that have occurred since its first appearance in a 1961 Osaka court case (LEX/DB: 27611297): 178 regional cases, 43 regional superior court cases, and 15 Supreme Court cases. ${ }^{4}$ We chronologically localize all 236 cases. In the second part, we offers a detailed text analysis of the first local case reference to the phrase lifetime employment, then textually explore phrase references as presented in the 15 Supreme Court cases, and end with content reference to lifetime employment in the latest Osaka regional superior court. We lastly review the most recent data available on labor - management communications forums in Japanese firms, based on the survey conducted every four years by the Ministry of Health, Welfare, and Labor (Minister’s Secretariat Statistical Information Department Salary and Welfare Statistics Section, 2010). Our concluding discussion considers implications of the research, outlines future directions, and offers suggestions on labor policy initiatives in light of the comparative cultural cognition data.

We pursue two processes as method for the Supreme Court population of references: data mining and judicial discourse analysis. Data mining is "the process of discovering meaningful new correlations, patterns and trends by sifting through large amount of data stored in repositories, using pattern recognition technologies as well as statistical and mathematical techniques" (Larose, 2005:2).

Next, we look at the Supreme Court cases as discourse. Robert Alexy (1983) stated that juristic discourse deals with special institutional stipulations as instances of general and practical

\footnotetext{
${ }^{4}$ The LED/DB citation method is explained below.
} 
discourse. The concept of practical reason or rationality is employed normatively. The end of such a discourse is "to ensure that the claim raised by juristic sentences can be rationally and reasonably justified, and to explicate and provide criteria for the rationality of juristic justification" (Oesir, 2003: 210).

The relationship between general practical discourse and juristic discourse can be interactive. Juristic discourse in its practicality is established through general practical discourse backed with reference to the relative indeterminacy of the results of such discourse in particular cases. On the other hand, juristic discourse, as it is enounced, enforces norms and their rationality in and for the public domain. In this, we are reminded of Habermas's view that the role of law is an instrument of stability and societal control (Habermas, 1996). In other words, the most critical work regarding the analysis of such discourse may concern the evaluation of power (defined in respect to groups) and linked with word use involving control and influence (van Dijk, 2008).

Finally, in respect to methods issues associated with legal studies in our project, we ask: in what way is the instrument of stability and societal control manifest? This question sharpens our interest in the discourse of Japan's Supreme Court concerning lifetime employment. The Supreme Court is not only the final resort - it also acts as the gatekeeper of Constitutional concerns in Japan. The Court holds oversight in respect to the set of established precedent according to which sovereign national power treats its people and organizations and sustains these as the set of principal guidance.

Through access to a Japanese proprietary legal data base, TKC Horitsu joho detabesu (TKC Law information data base, henceforth: LEX/DB, given at http://www.tkclex.ne.jp/ ), we conducted comprehensive searches of pre- and post-war case law for references to "lifetime 
employment" Searches were conducted at each of the three court levels: regional, regional superior, and Supreme Court. Ancillary searches of tax, criminal, or family court cases were also conducted. The proprietary nature of the data base precludes extensive replication of case law content, but we provide key text quotes in the Results section. In References, these cases are listed according to the LEX/DB case number with year of publication. The standard case law referencing information is also provided so that the cases texts can be sought through published Japanese law journals.

Data for cases referencing "lifetime employment" were compiled in an Office Excel spread sheet file. Case information was entered under these headings:

- Case number

- LEX/DB identification number

- Case date (Japanese and Western calendar)

- Court location: for regional and regional superior cases

- Japanese case identification: this differs from the LEX/DB identifiers

- Case source: appeal (for Supreme Court, there are no other types)

- LEX/DB case title

- LEX/DB case summary

- Type: wages, inheritance, dismissal, etc.

- Appeal source: public/private, male/female, sector, organization

- Defendant source: same categories as above

- User of 'lifetime employment' phrase

- Text of keyword usage (Japanese), and

- Other points. 
The authors then set about the collection and analysis of cases referencing our phrase of interest from quantitative and qualitative perspectives. Of particular significance was discovery of the earliest case, if this could be done, and then identification of all case references to the key phrase. In terms of method, it was important to establish whether the data base was producing a sample or a population of case references to the phrase in question.

In reference to these two particular interests - first case, all cases - the LEX/DB is a proprietary database, offered only in Japanese. ${ }^{5}$ It contains full text of court cases dating from Meiji 8 (1875) and is current to December 24, 2009. There are 224,371 legal cases in this data base, which include cases explicitly dealing with socio-economic issues, particularly in respect to Japan's labor legislation. The LEX/DB website states this database to be comprehensive. Accordingly, case "hits" referencing the phrase "lifetime employment" in Japanese should yield the entire population dating from the Meiji Restoration.

Contrary to la common misperception of Japan as a nation comparatively adverse to Western forms of legal disagreement, dispute, and formal actions, court cases initiated in Japan in any given year number in the hundreds of thousands and derive from disputes covering the entire range of socio-economic issues, including divorce and criminal proceedings, for example (Japan Statistics Bureau, 2011). Those that result in formal court decisions - the cases of our research interest - are far fewer; those involving issues of labor law fewer still. Thus, while it is possible the "real" data base population is larger than the LEX/DB database, which claims to contain the entire population of publicly available case law, this phrase-driven information technology approach to legal analysis brings social science as close to the actual population of case references to 'lifetime employment' as may currently obtain.

\footnotetext{
${ }^{5}$ The website is given at http://www.tkclex.ne.jp/ .
} 
In fact, due diligence for methodological transparency resulted in discovery that the vast majority of Japanese court case outcomes are not released to the public domain (Hiraoka, 2010). Referring to studies by the Japan Lawyers Association, Hiraoka reported a Supreme Court public-domain release rate of no more than $0.9 \%$.

In contrast to U.S. freedom of information approaches, Japan is not as open in all aspects of legal discourse and decision. Nevertheless, the available population of cases indicates "lifetime employment" is indeed referenced by the Court. That these references are included amongst disclosed court documentation suggests they are of great significance. Thus, all indications are that, in terms of research method, the cases referencing "lifetime employment" that we examine constitute the population of case law that resides in the public domain.

Search outcomes are reported in the Results section that follows. Results are presented in terms of quantitative / descriptive and qualitative analysis. The quantitative / descriptive analysis first presents summary statistics on "lifetime employment" references as they appear in case law from various aspects: date, region, type of court. Next, the Supreme Court references to case law are themselves examined in detail.

The qualitative assessment of Supreme Court references will address how the phrase "lifetime employment" was manifest in the cases where it appeared. We were interested in identifying referent source, purpose, and role of "lifetime employment" references in case law. Certainly, the single most important qualitative assessment concerned whether or not the courts acknowledged the factual existence of such a thing as "lifetime employment" in Japanese employment practice. The second qualitative issue of interest concerned whether or not, and in 
what manner, the various courts handled this observed practice, if indeed the courts acknowledged the existence of "lifetime employment" as prior research indicated. ${ }^{6}$

Here, a few incidental methods issues should be briefly noted. First, on discovery, we found that "lifetime employment” (shushin koyo, 終身雇用) case references coincided with references to a functional synonym (shogai koyo, 生涯雇用). As the current research agenda initially aimed to document case law references to “lifetime employment” (終身雇用), we noted this functionally synonymous phrase, conducted separate data searches to establish case counts and LEX/DB case identifiers, and simply incorporated both phrases into the investigation.

Second, limits of time and resources precluded a detailed content analysis of all the cases captured in the data search. Thus, as stated above, the qualitative analysis focused only on the first case reference (a regional court decision) and all Supreme Court decision references. In the qualitative portion of the study, the cited case law texts were read and interpretations crosschecked by the co-authors, both of whom are bi-lingual in English and Japanese; one is a native English speaker, the other a native speaker of Japanese.

The other data source of interest in this paper sheds light on Japan's collective-bargaining based management councils and other informal shopfloor forums. Japan's Ministry of Labor the Ministry of Health, Labor, and Welfare since 2001 - has conducted large-scale surveys of labor-management “communications” about every four or five years since 1972 (Tackney, 2002). ${ }^{7}$ The latest survey is from 2009 , reporting on data collected the prior year. The survey is national in scale, targeting 16 industrial sectors, and sampled 5,500 enterprise sites from amongst the national population of firms (Minister's Secretariat, 2010, and for subsequent data in this

\footnotetext{
${ }^{6}$ In this sense, the database search and analysis provides a check on the validity and reliability of prior claims that lifetime employment is a post-World War II institutionalized practice (Tackney, 1995; Kettler \& Tackney, 1997).

${ }^{7}$ The survey series is only available in Japanese.
} 
section). The survey also includes an appropriately random survey of about 6,500 workers. Response rates were, $65.3 \%$ for enterprises and $61 / 7 \%$ for workers. The stated purpose of the survey is "to clarify the conditions of consciousness, etc., for workers and enterprise side in respect to the method and utility conditions, etc., of measurement of mutual understanding of the sense of labor-management relations." In reporting this data, it should be kept in mind that Japan's employment relations system localizes management councils in collective bargaining agreements, but places no particular obligation on reporting items - these are unique to each agreement.

\section{DATA}

\section{Supreme Court Case law}

First, no case references to "lifetime employment" resulted from database search in the tax, criminal, or family court data bases. There were no references to "lifetime employment" in any pre-World War II case law data base search.

\section{Quantitative Aspects of Case Law References to Lifetime Employment}

Separate searches for "lifetime employment" were at the regional, regional superior, and Supreme Court levels in the on-line LEX/DB database over a period of months in 2010. A database "hit" would be any case having one or more textual references to the phrase within the case.

As the qualitative assessment proceeded, it became apparent that an alternative Chinese character for the second character in the word “employment" ( 雇用) was occasionally used in text: 雇傭. This alternative character does not change the meaning of the word; it merely reflects a particular writing preference. Neverthless, this required another comprehensive search by court 
level for "lifetime employment” ( 終身雇傭 ). Double referenced cases were noted. In the end, the total distribution of occurrences for either phrase was: 178 regional cases, 43 regional superior cases, and 15 Supreme Court cases.

The overall distributions can be readily summarized:

\author{
Lifetime Employment References \\ by Court Type
}

Regional Courts

Regional Superior Courts

Supreme Court
Count* First Occurance

178

15
July 19, $1961 \quad$ July 08,2010

November 27, 1962 July 16, 2009

December 25, 1968 February 28, 1997

(* - reflects either "employment" character: 終身雇用/終身雇傭. Data also given as Table 3.)

The numerical count indicates at least one use of the phrase "lifetime employment" within the text of the court decision - we are not, at this point, considering the context of the reference. Thus, a case decision may affirm the existence of lifetime employment in Japanese labor law, or deny it. All these figures indicate is explicit reference to the phrase. We explore context issues in the qualitative Supreme Court analysis to follow.

Before continuing with the descriptive statistics on "lifetime employment" references, two results-related issues should be noted. First, as mentioned in the Methods section, a functional synonym for "lifetime employment" was observed: shushin koyo / shogai koyo. Separate searches on this term turned up few additional cases: 1 Supreme Court, no additional regional superior cases, and three regional court cases. The one additional 1972 Supreme Court case was added to the qualitative assessment section to explore possible differences in nuance. 
Next, qualitative assessment prompted notice that “long term employment” （長期雇用/ 雇傭） was being referred to in case law. In one sense, this is not surprising, as regular employees in Japan have an indefinite contract. Nevertheless, it seemed useful to explore the number of references that occur in the population. So, we conducted searches of the population for references to this phrase. There was one Supreme Court case use without accompanying reference to "lifetime employment" in 1983. In addition, there were 27 regional superior court cases referencing this phrase that did not refer to "lifetime employment" at any point. And, finally, there were 118 regional court cases that referenced this phrase. We did not look for regional cases that referred exclusively to "long term employment" as opposed to "lifetime employment," due to time constraints. We wish to note that more recent court cases appear to favor this phrase. Perhaps more significant, references to "long term employment" in regional case law predate the first appearance of "lifetime employment" - the earliest case occurrences are in 1955 (LEX/DB 27610676) and 1960 (LEX/DB 27611187).

Table 1 reports the distribution of cases references to "lifetime employment" by regional court. Most occur in Osaka and Tokyo regional courts. In contrast, Tokyo is the center of case references to "lifetime employment" at the superior regional court level, as evident in Table 2.

Table 3 provides summary statistics on the number and chronological range of cases in each of the three court types. This is, perhaps, the most important descriptive Table. There have been 178 regional cases referencing "lifetime employment" from July 19, 1961 to July 08, 2010. The population of regional superior court cases is 43, beginning November 27, 1962 until July 16, 2009. Finally, the 15 Supreme Court cases referencing the phrase range from December 25, 1968 to February 28, 1997. 
Insert Figure 1 here.

The longitudinal distribution of case references by court type are given in Figure 1. First, as previously mentioned, there are no pre-World War II occurrences. The initial regional case events began in the 1960s. As might be expected, time lags obtain for regional superior and Supreme Court case events as these proceed on appeal. The more numerous regional case frequencies peak in 1979-81 and again around the year 2000, which has the greatest event count of 13 court case references. In the next section we take a closer look at the use of "lifetime employment" in the context of Japanese Supreme Court references.

\section{Qualitative Aspects of Supreme Court Case Law References to Lifetime Employment}

In regard to the Supreme Court cases the earliest occurrence is in 1968 and the latest in 1997. The phrase "lifetime employment" is used 25 times. How did the Supreme Court judges pronounce on the possible existence and nature of "lifetime employment" based on the population of references reviewed? Three points appear most significant.

First, the most significant fact appears to be lifetime employment is the Court perceives this to be a premise or general practice. In eight among the 15 cases lifetime employment is explicitly referred to as "our nation's practice" or "prima facie premise". Although the usage of the term, lifetime employment, in the 1995 Supreme Court case is limited to the plaintiff's working relation alone, in all other cases, including the latest case ruling of 1997, the judges acknowledge lifetime employment as a societal practice. Even if the Court remarks on the changing nature of lifetime employment (LEX/DB, 247814696), on a level of rhetoric the statement points to the fact that lifetime employment has existed in Japan to that time. 
Second, the Court also uses "lifetime employment" with an adjacent character noun: 制 or 制度 (sei, or seido). This happened in seven cases, or $46.7 \%$ of the total population: shushin koyosei or shushin koyo seido. Significantly, the word sei is seen an abbreviation for seido, which is translated as system or institution in English. ${ }^{8}$

What are the implications of these numbers? There are three issues to discuss. The first issue concerns the nature of lifetime employment - and this relates to the second point made earlier. What is repeatedly stated in the Supreme Court is that lifetime employment is a system or institution. This stands in direct contrast to a stream of scholars who simply deny the existence of what Japan's highest court recognizes as an institutionalized practice.

Particularly for regular employees in Japan, but also for term contract employees who experience repeated contract renewals, Japan's lifetime employment system exists as an institutionalized practice that offers a degree of support for the continuance of an explicitly indefinite or implicitly continually renewed term contract employment relation. Sugeno, who does not report on the fact of these Supreme Court decisions in his Japanese Labor Law text, does note a "social model" of a "long-term employment eystem" in Japan - a "practice' offering a substantial degree of job security that approaches $20 \%$ of the labor force, as measured by regular employees as a percent of the work force and extending in an informal manner to repeatedly renewed term contract employment relations (Sugeno, 1992).

The Supreme Court enounces this lifetime employment system and enforces it in society. This opportunity arises in the course of a labor dispute taken to court in connection to the contractual duration of an employee's service of labor or for other causes. At this point, the

\footnotetext{
${ }^{8}$ http://nihongo-e-na.com/eng/site/id241.html, a Japanese on-line dictionary from the well-establish Sanseido.
} 
Court proactively refers to and makes determinations regarding the extant social systems or institutions in Japan, in this case the lifetime employment system.

In reviewing the context of references, lifetime employment appears to be a double-edged sword. It is acknowledged to exist for employment security and a promised future. The Court in 1979 saw that such expectations may oblige young graduates in an appurtenant right or manner. That is to say, it is a phenomenon in which a dependant right resides in association to a larger right or responsibility set. In practice, this means that new employees agree to working rules already established at the time of employment. There exists an unspoken, tacit agreement regarding actual subsequent enactment. Because of this, an ongoing human relation may be associated with the contract, beyond the simple supply of physical labor as commodity (LEX/DB 27000174, 27000194). Yet, there is another implication that follows from this legal judgment, which the Court also recognized. Because the lifetime employment system is so prevalent in Japan, labor conditions are comparatively restricted in terms of labor mobility (LEX/DB 27000124).

The Supreme Court uses "lifetime employment" or "lifetime employment system" carefully. For instance, in a 1983 case, the Court acknowledged that the lifetime employment system is gradually changing and, "merit based employment relations are growing. In small and medium firms in particular duration of ten years is not necessarily short for workers to be employed by a same employer" (LEX/DB 21080054: 7-8). The 1991 case stated, “it is necessary to attend to the fact that our nation's lifetime employment itself is becoming other than a general employment form” (LEX/DB 27814696: 6).

This last point dates from a June 1991 case. By the following autumn, Japan's so-called bubble economy had begun to burst. From our retrospective view at the end of 2011, this 20 year 
old judgment appears to have anticipated a degree of change in Japan's labor relations. As annual-basis salary systems and merit-based employment increased, more viable limited-term contracts were introduced, and this against the background of the Worker Dispatch Law, itself effective since 1985 (Suzuki, 2010).

In addition to tracking dynamism in the employment sector, the Court cases also manifest continuity in Japan's labor law spirit, which we consider as our third point of analysis in judicial discourse. A certain principle becomes evident in reading the varied context of phrase use in these Supreme Court decisions. To explicate this point in detail, we will take up the most representative case, which is the one where the phrase lifetime employment was used the first time in Japan's Supreme Court history (LEX/DB 27000859). The case was first filed as a lawsuit in 1965. The plaintiff (male) was a deputy director in a branch of a private transportation company. Short after the plaintiff turned 55 years of age, he was suddenly forced to retire according to the firm's newly and secretly established retirement age rule, which stated that staff above than a rank of supervisor should retire at 55. There was no such retirement age rule for managers in this company before.

The plaintiff resisted the new working rule, but he was forced to leave in the end. The first trial found in favor of the plaintiff. The firm, as defendant, appealed and won the second trial. The key sentence from the second trial follows;

No definite retirement age in a labor contract only means there is no definite employment period, and it does not mean to assure employees lifetime employment or to mean to not employ a retirement age system in the future. A fact of so-called lifetime employment does not additionally go beyond the meaning of a continuing employment possibility and cannot mean to allow labor for such established rights, unless one's labor contract and working rules stipulates these specifically (LEX/DB 27000859: 3). 
Against the regional level outcome, the plaintiff appealed to the Supreme Court. The case was ruled on December 25, 1968. The Supreme Court dismissed the Regional Superior Court decision. Its first argument was on rationalization.
Although gaining the maximum productivity by employing a cheap and high quality labor force as small as possible can be an absolute must for the employer, this is nothing more than the intensification of labor for employees. The so-called economic rationalization possesses an undoubted "rationality" if it stands for employers. For labor, this is the ultimate exploitation. We see the fact that there is a discrepancy between the younger laborers and the older laborers in regard to their views on the retirement at age 55. It cannot be recognized, however, that this is rational enough only because the employer promoted it and some employees agreed. Recognizing 55 years old as retirement age is gradually becoming a product of past (LEX/DB 27000859: 12).

The Supreme Court went on to point out that the firm negotiated many times with its labor union when it established the mandatory retirement age for general employees back in 1951. Thus, the firm was quite cognizant of the fact that the retirement age system could not function without the union's support. Furthermore, the firm was aware of the fact that it could not dismiss its employees in a unilateral way as long as the employees have an indefinite term employment contract. The Court's reasoning concluded,

The firm abused its power against a manager who was not allowed to be a union member. (This reveals the appellee's $<$ the firm, in this case $>$ ) non cooperative, dictatorial attitude. This ill-treatment has forgotten that the building up one enterprise together with the employer and the employee is never far from possible abuse of power. ...(and) rejecting such abuse of power is just in regard to the operation of law (Ibid.: 18-19).

Let us recapitulate the key points of this textual analysis. The Supreme Court noted that the building-up of one enterprise is due to both employer and employees. Yet, abuse of power may occur in such a building-up process. The Court declared that it is an operation of law to reject the abuse of power, according to what is just. While law is not distinguishable from morality, according to Habermas, the specific point which differentiates law from morality is that “discursively justified and applied norms have a legal form, i.e., they are enacted politically, 
interpreted in a binding manner, and enforced with the threat of state sanctions" (1998: 436, italics by Habermas).

Thus, here in this Supreme Court case, we have a key moment of judicial discourse, which we may characterize as a discourse of justness. The term, justness, refers to what is made according to principle, in a manner that is equitable as well as proper. The discourse of justness is a discursive medium through which the spirit of Japan's labor law is made manifest against a range of potential abuses. In the instance, the Court ruled against an abuse of managerial prerogative.

This discourse of justness has since been interpreted, enacted, and enforced by Japan's courts, particularly the Supreme Court. Notably, the Court has developed this discourse in relation to the institutionalized practice of lifetime employment, which it recognized for the first time in this landmark decision.

\section{The Status and Role of Labor-management Communications in Japan}

In a July, 1946 advisory document from Japan's Central Labor Relations Commission, management councils were recommended to be establish in collective bargaining agreements given consent of both management and labor union. Specific issues to be addressed by these councils were left up to the parties to each agreement, but no prior restraint was placed on the potential range of discourse, unlike legislative enactments for works councils as in Germany and, much later, the European Union.

Data from the 2009 survey described in the Methods section indicate some $75 \%$ of firms with 5,000 or more employees in 2009 reported management councils (80\% in 2004) (Minister's Secretariat, 2010). For shop-floor consultation meetings, the figures for the same firm scale were 
$69 \%$ (72\% in 2004). For both forms of consultation, these figures steadily drop off as firm size decreases, as may be expected - smaller firms would require fewer formal consultative structure.

In 2009, unionized enterprises have management councils $83 \%$ of the time in contrast to $20 \%$ of non-unionized firms. Overall, $93.5 \%$ of firms with 5,000 or more employees reported "labor-management communications" to be "important". The variance between unionized and non-unionized firms indicated that $95 \%$ of unionized firms held labor-management communications to be important; this figure for non-unionized firms was $84 \%$.

The following list summarizes the items taken up in management council among all firms reporting their presence in 2009. This is particularly salient because of the collective-bargaining specific nature of topical issues, which makes generalizations difficult without such enterprisespecific surveys.

$$
\text { Mutual assent Cooperation Hearing Explanation Not an item }
$$

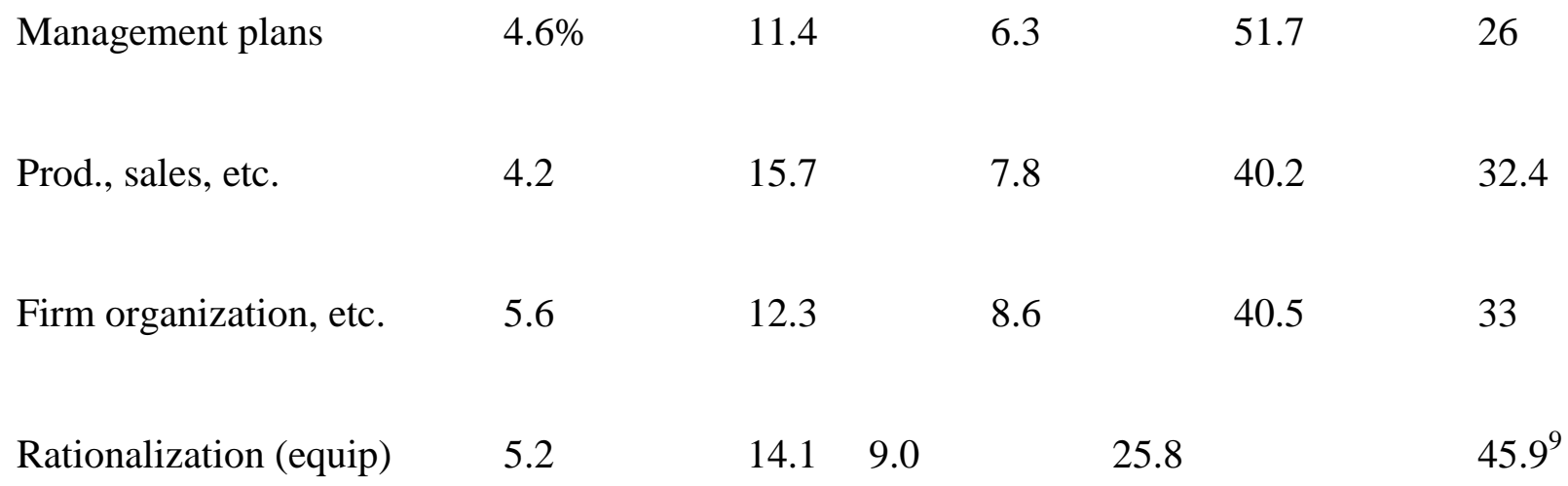

Approximately $15 \%$ of firms reporting management councils report operations over a range of topics in which explicit co-determination (approx.. 5\%) or pro-active engagement of employees is normative. The range of topics include: temporary lay-offs, personnel reductions, dismissals, retirement, job scope enlargement, re-hire, working hours, vacation, parental leave,

\footnotetext{
${ }^{9}$ It would be important to note for this item that Japanese case law functionally precludes rationalization dismissals simply due to manufacturing process rationalizations. Thus, "rationalization" in the Japanese sense have a completely different meaning than in an 'at will' legal culture.
} 
wages, bonuses, overtime rates, and pensions. The percentage for each item exceeds $50 \%$ of all management council firms if a less engaged "cooperation" dynamic is included. ${ }^{10}$ Historically, the current survey data reflects little change over the past five survey periods, which occur at five year intervals.

What should be evident from this data is the functional difference in kind that exists between Japanese and U.S. firms in respect to their internal labor-management ecology, particularly concerning fiscal details of enterprise operations and profit determinations. To be clear, given mutual consent, items not previously specified in collective bargaining can be taken up in management council discourse. Indeed, the mere possibility of issues being raised appears to serve as a useful silent threat mechanism to discourage inordinate compensation demands on the executive side in Japan, a point readily acknowledged by a Toyota labor union representative in conversation (Tackney, 2009).

\section{DISCUSSION}

Our aim was to comparatively explore social policy in two nations sharing similar labor legislation but enacting very different patterns of employment relations. In terms of research design method, the United States and Japan offer an unusual historical, quasi-experimental social policy analysis venue, in that these nations share labor legislative foundations, yet manifest very divergent social policy outcomes for regulation of managerial prerogative in society. To investigate these differences, the authors deployed data mining and discourse analysis inquiries into Japan's Supreme Court decisions, at the maco-level, and study of national data on management councils at the firm-specific micro-level.

\footnotetext{
${ }^{10}$ Again, for matters touching on dismissals due to persistently poor firm performance, Japanese case law severely restricts targeted dismissals of the workforce, having firmly decided over many decades that poor enterprise performance is firstly due to poor management. Reduction in executive compensation in Japanese firms is the first expected step prior to redundancy dismissals. Consultation with the workforce and good faith effort to solicit consent from those to be dismissed are additional case law expectations. See Kettler and Tackney, 1995.
} 
We thought this effort could also serve as a contribution to emerging legal studies literature on cultural cognition, by adding an international, comparative legal dimension. On the Japan side, there was a macro-level and one micro-level goal. The macro goal was an analysis of the Japanese Supreme Court discourse on lifetime employment, which has never before been studied. The analysis disclosed a discourse of justness in principles consistent with just cause employment protection, the right of employees to express voice in management consultation and other forums, and an exercise of care in respect to the potential for management to abuse managerial prerogative. To the authors' knowledge, there simply is no parallel discourse in the United States, as lifetime employment does not appear to be a matter ever brought before the U.S. Supreme Court. ${ }^{11}$ Altogether, these pages help to explicate the mechanisms and social process hinted at by Ronald Dore in 1973. He wrote, "In Japan a sufficient number of firms in a sufficiently dominant position deviated far enough from market principles of employment to form a 'critical mass' capable of changing the character of the system as a whole" (Dore, 1973: 407). That said, the institutionalized practice of lifetime employment - as regulated in case law stands as a societal norm and expectation in the form of a customary law (kanshuho). This fact of Japanese society is also readily acknowledged in daily life - absent compelling fiscal crisis, regular employees are viewed to have a reasonable expectation of the continuance of their indefinite employment contract. ${ }^{12}$ We have also been able to characterize the nature and extent of employee participation in Japanese managerial prerogative.

Through case law, directly or by implication, lifetime employment as a phenomenon of Japanese employment practice arose in the context of Suehiro jurisprudence. Because of this

\footnotetext{
${ }^{11}$ As a U.S. legal issue, "lifetime employment" occasionally comes up in respect to verbal or written promises. Only the latter holds sway in the U.S. An October 23, 2009 U.S. Court of Appeals, Second Circuit case involved plaintiff claims (Margaret Sipser Leibowitz) of lifetime employment assurances by the Cornell University, N.Y. State School of Industrial and Labor Relations. The plaintiff claims vacated on appeal (Docket 584 F.3d 487 (2009)).

12 This point, along with discussion of the profound influence of Suehiro jurisprudence for Japanese case studies and labor law is taken up in Kettler \& Tackney 1997.
} 
extrinsic conditioning of the rules governing employment relation - and from the very early postwar years - Japanese management practice was extrinsically encouraged and restrained in its prerogatives in such a manner that Dore's "critical mass" could - as a significant factor in Japan's political economy - shift away from the U.S. conflictual approach to labor relations fundamentally offered in Japan's postwar labor legislation.

From a comparative labor law perspective, there is much the U.S. employment circumstance may learn from Japan's half century experience with essentially similar labor legislation. Some scholars have proposed the adoption of Japanese practices to the U.S. context (Gould, 1984, 1993). Ironically, one of the Japanese Supreme Court case references to "lifetime employment" occurred because the Court quoted a U.S. public sector study of labor, wherein the phrase appears in Japanese translation (Godine, 1951). The distinct referencing by the Supreme Court to lifetime employment as an institution or practice and an understanding of the nature of this discourse substantially helps to explain the contested and contesting domain this practice has been. In ordinary conversation, Japanese tend to speak of lifetime employment as a tradition with uncertain future prospect, or something already passé. Too, there has been a long-standing media propensity to deny its reality or point to its imminent demise (Takahashi, 2010). These negations appear to derive from the fact that lifetime employment is not something explicitly regulated by legislative enactment. That said, the practice - as regulated in case law - stands as a societal norm and expectation in the form of a customary law (kanshuho). And this fact of Japanese society is also readily acknowledged in daily life - absent compelling fiscal crisis, regular employees are viewed to have a reasonable expectation of the continuance of their indefinite employment contract. ${ }^{13}$

\footnotetext{
${ }^{13}$ This point, along with discussion of the profound influence of Suehiro jurisprudence for Japanese case studies and labor law is taken up in Kettler \& Tackney 1997.
} 
In consequence, subsequent Japanese management theories - in fact, the entire range of them - require reassessment insofar as they posit the historical emergence of successful "Japanese management" outcomes based strictly or solely upon firm-intrinsic causal attribution or analysis. To mention two such theories: both the "white collarization" construct of Koike and the "J-firm" of Aoki would be more valid if recognition were made of the role of Japanese labor jurisprudence. In a word, comparative jurisprudence is critically important to correctly grasp why Japan's postwar economic miracle in employment relations succeeded, particularly concerning its social policy dimension. This research is a corrective step and one that highlights the informal network features of Japan's employment relations system.

The moderating role of Japan's courts concerning abuse of management prerogative doctrine cannot be overstated. It serves as an important national instrument for social policy in respect to the functioning nature of the business enterprise in Japanese society. The discourse of justness by which we characterize the content of decisions, noted above, pervades regional and regional superior case law to a greater degree than the Supreme Court cases cited. In this, we recall the earlier reference to Habermas in characterizing law as an instrument of stability and societal control. Van Dijk's point that power is evidenced in society in terms of control and influence helps to understand the Court's appreciation for the double-edged sword that the institutionalized practice of lifetime employment has developed into.

In this sense, we can link this point of view to the influential legacy of Izutaro Suehiro. As the father of Japanese labor law, his sociology of law-based jurisprudence clearly recognized that the employment contract was not between equal parties, rather - consistent with continental European jurisprudence - the employee required judicial protections against potential abuse by the more dominant party to contract: the employing firm (Dean, 2002; Oda, 1993). 
Furthermore, it would seem indeterminate, at this junction, if "Japanese management" practice can be successfully implemented in a broad manner solely due to the reasonably longterm vision of managers, as Aoki's theorizing would have it. Certainly the mass layoffs, strikes, and courtroom struggles of organized labor following the Dodge Line economic rationalizations early in the postwar period preclude a simple continuity from observed, if limited, patterns to retain managerial staff in Japan's early pre-World War II industrialization. Similarly, overseas export of the institutionalized practice may not succeed absent sufficient learning by all parties involved, along with judicial support in justness.

Whether or not this institutionalized practice continues is a matter for the courts to determine, as they appear fully competent to do. The Supreme Court has noted, in at least two cases, that changes may be underway. For example, the 1992 Court recognized that women were not often included in this postwar institutionalized practice (LEX/DB 27819830). In this connection, the earlier case reference found to "long term employment" - as early as 1955 - hints at the underlying legal constructs that have helped give rise to the particular and arguably popular social characterization of "lifetime employment." The frequent recent case law referencing of this phrase, and its regulation, may also hint at future parameters should Japanese sensibilities for "lifetime employment" substantially change.

In this paper, we examined how a discourse of justness has been elaborated in Supreme Court decisions concerning the institutionalized practice of lifetime employment in Japan. This discourse has profound implications for the study of informal network structures in Japan's employment relations system and suggests a corrective, alternative venue to the strategic-choice behaviors of U.S. management to date. The transnational diffusion of "Japanese management practice" is a way to actualize a more participatory approach to employment relations. These two 
research streams, lifetime employment and Japanese management theory, remain related; they are linked in the discourse of justness, economic sustainability of firm and organization, and the good of social order. In no small part, this is the legacy of Suehiro jurisprudence, the outcome of which Dore clearly recognized as the postwar "critical mass" in 1973.

Cultural cognition seems to be a useful comparative heuristic to account for the divergent approaches to employment relations in Japan and the United States. The lifetime employment development in postwar Japan appears to validate perceptions that Japanese society values communitarian and enterprise egalitarian values. Curiously, Japan is also known as a very hierarchically arranged culture. In this seeming contradiction, the grounds for the recent Olympus governance scandal may become comprehensible. While Olympus maintained external auditors, the larger reporting obligation was not as exacting as would be expected in U.S. enterprise governance. Thus, the cognitional bias toward hierarchy may have clouded appropriate behaviors.

For the U.S., cultural cognition studies have already yielded better understanding of and specific proposals to counteract domestic anti-labor tendencies. Hogler and Henle (2011) advocate less emphasis on reactive organized labor sentimentality than pro-active legal initiatives, but these in a manner conducive to hierarchical - individualist heuristic cultural sentiments. They wrote, “...unions should seek to undo existing laws. ...In Oklahoma, for example, a measure protecting worker from arbitrary discharge might attract widespread support, since it is an immediate and easily understandable gain for workers" (p. 143).

This research suggests another possible legal venue. It is not a great reach in American labor relations history to recover John R. Commons sentiment that employees have an obvious interest in the long-term success of a firm, or that they would share an interest in associated 
managerial prerogative. The product of their labor power is, thus, itself a contributory factor to the success of property, even if this property is not nominally defined in current U.S. law as belonging to anyone other than the owners. Excessive and inordinate executive compensation has already become the target of legislative efforts and what are known as 'clawback' legal actions. Experimentation in collective-bargaining based management participation, the lesson to be learned from Japan, could readily be permitted by the NLRB. This step has already been proposed (Dunlop Commission, 1994). We know from Japan that this alone can moderate management compensation levels. Furthermore, in light of the more authentic appreciation of modern employee output Commons long-ago recognized and recent studies further confirm, current U.S. executive compensation levels may well be actionable under the equal protection clause of the $14^{\text {th }}$ Amendment to the U.S. Constitution, as excessive self-appropriation of profit violates, on each point, a citizen's due process equal protection "of life, liberty, or property." 


\section{REFERENCES}

Abegglen, J.C. 1958. The Japanese factory: Aspects of its social organization. Glencoe: Free Press Alexy, R. 1989. A theory of legal argumentation: The theory of rational discourse as theory of legal justification. Gloucestershire, U.K.: Clarendon Press.

Aoki, M. 1988. Information, incentives and bargaining in the Japanese economy. Cambridge: Cambridge University Press.

Beck, J. \& Beck, M.N. 1994. The change of a lifetime: employment patterns among Japan's managerial elite. Honolulu: University of Honolulu Press.

Cole, R. 1979. Work, mobility, and participation: a comparative study of American and Japanese industry. Berkeley: University of California Press.

Commons, J.R. 1924. Legal foundations of capitalism. New York: Macmillan.

Dean, M. 2002. Japanese legal system (2nd Edition). London: Cavendish Publishing.

Dore, R. 1973. British factory-Japanese factory: the origins of national diversity in industrial relations. London: George Allen and Unwin, Ltd.

Dunlop Commission. 1994. The Dunlop Commission on the future of worker-management relations - Final Report.DigitalCommons@ILR, Cornell University ILR School. Retrieved from http://digitalcommons.ilr.cornell.edu/key workplace/2/ .

Dunlop, J.T. 1958. Industrial relations systems. New York: Henry Holt.

Dunlop, J.T. 1993. Industrial relations systems (Revised Edition). Boston: Harvard Business School Press.

Foss, N. J. 1999. Networks, Capabilities, and Competitive advantage. Scandinavian Journal of Management, 15(1), 1-15.

Gerlach, M.L. 1997. Alliance capitalism: The social organization of Japanese business. Berkeley: University of California Press.

Godine, M.R. 1951. The labour problem in the public sector. Dorset: Russell and Russell

Gould, W.B. 1984. Japan's reshaping of American labor law. Cambridge: MIT Press.

Gould, W.B. 1993. Agenda for reform: the future of employment relations and the law. Cambridge: MIT Press.

Gould, W. B. December 16, 2011. Crippling the Right to Organize. The New York Times. New York. 
Habermas, J. 1996. Between facts and norms. Polity Press, Cambridge.

Habermas, J. 1998. Reply to symposium participants, Benjamin N. Cardozo School of law. In M. Rosenfeld (Ed.). Habermas on law and democracy. Berkeley: University of California Press.

Halberstam, D. 1986. The reckoning. New York: William Marrow.

Hiraoka, A. 2010. Nikon a hochikokka ka-hanrei kokairitsu 0.9\% no shogeki (Is Japan a law abiding nation? The shock of a $0.9 \%$ public case law rate). http://www.senkensoi.net/column/2010/07/2774 retrieved in January 5,2011 .

Hogler, R., \& Henle, C. 2011. The Attack on the Public Sector Unions in the United States: How Regional Culture Influences Legal Policy. Labor Law Journal, 62(3), 136-144.

Japan Statistics Bureau 2011. Japan statistical yearbook. Tokyo: Ministry of Internal Affairs and Communications. http://www.stat.go.jp/english/data/nenkan/index.htm, retrieved January 10, 2011.

Kahan, Dan M. 2006. Cultural Cognition and Public Policy. Yale Law School Faculty Scholarship Series, Faculty Scholarship Series, Paper 103. Retrieved from http://digitalcommons.law.yale.edu/fas_papers/103

Kahan, Dan M. 2011. Cultural Cognition as a Conception of the Cultural Theoy of Risk. Handbook of Risk Theory. London: Springer. Retrieved from http://ssrn.com/abstract=1123807.

Kahan, Dan M., Slovic, P., Braman, D., \& Gastil, J. (2006). Fear of Democracy: A Cultural Critique of Sunstein on Risk. Harvard Law Review, 119, 1071-1109.

Kettler, D., \& Tackney, C.T. 1997. Light from a Dead Sun: the Japanese Lifetime Employment System and Weimar Labour Law. Comparative labor law and policy journal, 19:1. 101-141.

Kochan, T. A., Katz, H. C., \& McKersie, R. B. 1986. The Transformation of American Industrial Relations. New York: Basic Books.

Koike, K. 1988. Understanding industrial relations in modern Japan. London: Macmillan.

Larose, D. T. 2005. Discovering knowledge in data: An introduction to data mining. Hoboken, NJ: John Wiley \& Sons.

Levine, S.B. 1958. Industrial relations in postwar Japan. Urbana: University of Illinois Press.

Lincoln, J. R, G., M.L. 2004. Japan's Network Economy: Structure, Persistence, and Change. Cambridge: Cambridge University Press. 
Minister's Secretariat Statistical Information Department Salary and Wefare Statistics Section. 2010. Heisei 21 nen roshi komyunikeshon chosa kekka no gaikyo (2009 Outlook on the Industrial Relations Communications Survey Results). Tokyo. Retrieved from http://www.mhlw.go.jp/toukei/itiran/roudou/roushi/jittai/jittai09/index.html

Morrison, E. W. (2011). Employee Voice Behavior: Integration and Directions for Future Research. The Academy of Management Annals, 5(1), 373-412.

Moyers, B. January 20, 2006. PBS Politics and Economy: Executive Pay. Retrieved from http://www.pbs.org/now/politics/executivepay06.html

Nakazato, M., Ramseyer, J. M., \& Rasmusen, E. B. 2006. Executive Compensation in Japan: Estimating Levels and Determinants from Tax Records. Harvard Law School, Harvard Law School John M. Olin Center for Law, Economics and Business Discussion Paper Series.

Nonaka, I., \& Takeuchi, H. 1995. The knowledge-creating company: How Japanese companies create the dynamics of innovation. New York: Oxford University Press.

Nonaka, I. 2005. Managing Organizational Knowledge: Theoretical and Methodological Foundations. Great Minds in Management: The Process of Theory and Development. Oxford: Oxford University Press.

Numagamai, T., Karube, M., and Kato, T. 2010. Organizational deadweight: Learning from Japan. Perspectives: The Academy of Management. 24:4, 25-38.

Oda, Hiroshi 1993. Japanese law. London: Butterworths.

Oesir, E. 2003. Evolution and constitution: The evolutionary selfconstruction of law. Dordrecht, Netherland: Kluwer Academic Publishers.

Schreiter, R. 1985. Constructing local theologies. Maryknoll: Orbis Books.

Shimada, H. 1992. Japan's industrial culture and labor-management relations. In S. Kumon and H. Rosovsky (Eds.). The political economy of Japan, Vol. 3, cultural and social dynamics: 267-291. Stanford: Stanford University Press.

Sugeno, K. 1992. Japanese labor law. Seattle: University of Washington Press.

Suzuki, A. (Ed.). 2010. Shin jiyushugi to rodo (The new liberalism and labor). Tokyo: Ochanomizu Shoten.

Tackney, C.T. 1995. Institutionalization of the lifetime employment system. Ph.D. dissertation, UMI No. 9608158. Madison, Industrial Relations Research Institute, University of Wisconsin-Madison. 
Tackney, Charles T. 2001. The Modes of Social Relation in Japanese Management Practice. In Chapter 13, Cary L. Cooper, Sue Cartwright, and P. Christopher Earley (Eds.), The International Handbook of Organizational Culture and Climate: 377-390. New York: John Wiley \& Sons.

Tackney, Charles T. 2002. Management Participation (keiei sanka) in Japan and the Asian Crisis. In L. Tomba (Ed.), East Asian Capitalism: Conflicts, Growth, and Crisis: 347-372. Milano: Feltrinelli.

Tackney, Charles T. 2009. Yes, the U.S. Auto Industry Can - If the U.S. Congress and Obama Administration Learn a Lesson From Japan. Journal of Employee Rights and Responsibility, 21, 163-164.

Takahashi, Y. 2010. “Kigyo shakai” sairon. In A. Suzuki (Ed.), Shin-jiyushugi to rodo (New Liberalism and Labor). Tokyo: Ochanomizu Shobo. 45-69

van Dijk, T. 2008. Discourse and power. Houndsmill: Palgrave McMillan.

\section{Japanese Case Law References (in text)}

\begin{tabular}{|c|c|c|c|}
\hline LEX/DB ID & Case Type & Date (Japanese Calendar) & Year \\
\hline 27611187 & 昭和 31 年 (モ) 第398号 Regional & 昭和 35 年 5 月 14 日 & 1960 \\
\hline 27611297 & 昭和 31 年 (ヨ) 第 48 号 Regional & 昭和 36 年 7 月 19 日 & 1961 \\
\hline 27000859 & 昭和43年 (才) 第932号 Supreme C. & 昭和 48 年 12 月 12 日 & 1973 \\
\hline 27610676 & 昭和 44 年（あ）第 1501 号 SC & 昭和 49 年 11 月 & 1974 \\
\hline 27000194 & 昭和 54 年 7 月 20 日 $1979 \mathrm{SC}$ & 昭和 54 年 7 月 20 日 & 1979 \\
\hline 27000174 & 昭和 54 年 (才) 第 580 号 SC & 昭和 55 年 5 月 30 日 & 1980 \\
\hline 27000124 & 昭和 51 年 (才) 第1273号 SC & 昭和 56 年 9 月 18 日 & 1981 \\
\hline 21080054 & 昭和 54 年 (行ツ) 第 35 号 SC & 昭和 58 年 12 月 6 日 & 1983 \\
\hline 27814696 & 平成 3 年 (才) 第 211 号 $\mathrm{SC}$ & 平成 3 年 6 月 18 日 & 1991 \\
\hline 27814696 & 平成 3 年 (オ) 第 211 号 SC & 3 年 6 月 18 日 & 1991 \\
\hline 27819830 & 平成 4 年 (オ) 第 79 号 SC & 4 年 10 月 20 日 & 1992 \\
\hline 28020596 & 平成 4 年 (オ) 第 2122 号 $\mathrm{SC}$ & 平成 9 年 2 月 28 日 & 1997 \\
\hline
\end{tabular}

TKC 法律情報データベース (TKC Law information data base). Given at http://www.tkclex.ne.jp/ . The data base is proprietary and only available in Japanese. 
Table 1: "Lifetime employment" References in Regional Case Law by Rate

\begin{tabular}{|c|c|}
\hline Court location & Count (Combined "Employment") \\
\hline Osaka & 45 \\
\hline Tokyo & 42 \\
\hline Nagoya & 9 \\
\hline Kyoto & 8 \\
\hline Fukuoka & 8 \\
\hline Yokohama & 6 \\
\hline Niigata & 6 \\
\hline Chiba & 4 \\
\hline Kobe & 4 \\
\hline Aomori & 3 \\
\hline Gifu & 3 \\
\hline Hiroshima & 3 \\
\hline Matsuyama & 3 \\
\hline Nagasaki & 3 \\
\hline Okayama & 3 \\
\hline Asahigawa & 2 \\
\hline Fukushima & 2 \\
\hline Kanazawa & 2 \\
\hline Kushiro & 2 \\
\hline Miyazaki & 2 \\
\hline Morioka & 2 \\
\hline Nagano & 2 \\
\hline Oita & 2 \\
\hline Okazaki & 2 \\
\hline Sapporo & 2 \\
\hline Urawa & 2 \\
\hline Kumamoto & 1 \\
\hline Fukuyama & 1 \\
\hline Kofu & 1 \\
\hline Matsui & 1 \\
\hline Otsu & 1 \\
\hline Yamaguchi & 1 \\
\hline Total: & 178 \\
\hline
\end{tabular}


Table 2: "Lifetime employment" References in Regional Superior Case law

$\begin{array}{ll}\text { Court location } & \text { Count (Combined "Employment") } \\ \text { Tokyo } & 23 \\ \text { Osaka } & 7 \\ \text { Sapporo } & 4 \\ \text { Nagoya } & 3 \\ \text { Takamatsu } & 3 \\ \text { Fukuoka } & 2 \\ \text { Sendai } & 1 \\ & \text { Total: } 43\end{array}$

Table 3: "Lifetime Employment" References in Case by Court Type

$\begin{array}{lcll}\text { Court Type } & \text { Count* } & \text { First Occurrence } & \text { Most Recent } \\ \text { Regional Courts } & 178 & \text { July 19, 1961 } & \text { July 08 2010 } \\ \text { Regional Superior Courts } & 43 & \text { November 27 1962 } & \text { July 16 2009 } \\ \text { Supreme Court } & 15 & \text { December 25, 1968 } & \text { February 28, 1997 } \\ \text { * - reflects combined "employment" character use } & \end{array}$


Figure 1: "Lifetime employment" Case Occurrences 1950-2010

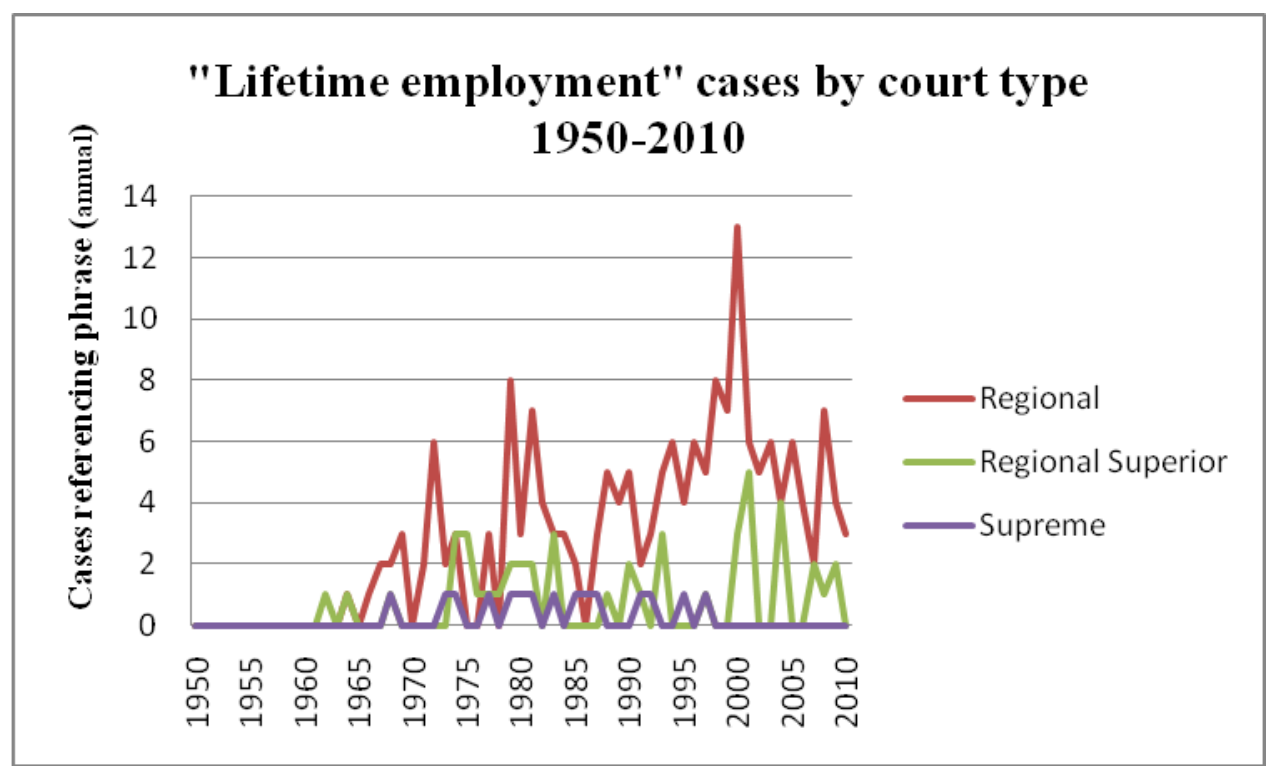

